\title{
Celebración metropolitana del Día de Muertos. Comunalización/Comunidad, MIGRACIÓN, MEMORIA FESTIVA Y RESISTENCIA EN BUENOS AiRES Y SANTIAGO
}

\author{
Metrobolitan Celebration of the Day of the Dead \\ Communalization/Community, Festive Memory and Resistance in Buenos \\ AIRES AND SANTIAGO
}

\author{
Pablo Mardones* \\ Francisca Fernández**
}

DOI: http://dx.doi.org/10.29043/liminar.v19i2.852

\begin{abstract}
Resumen: En el artículo se compara la celebración del Día de Muertos del cementerio de Flores y barrios del suroeste de Buenos Aires (Argentina) con la del Cementerio General y Cerro Blanco de Santiago (Chile). En el primer caso, la celebración la realizan migrantes aymara, qolla y quechua provenientes de los Andes centrales, y en el segundo mestizos urbanos que incorporan prácticas "andinas" como reapropiación simbólica identitaria. A partir de una participación observante se revisaron procesos de comunalización/comunalidad en la resignificación del festejo, con el centro en los repertorios interpretativos-culturales. Se concluye que en estas prácticas se han ido construyendo memorias festivas de resistencia, lo que ha producido nuevos sentidos de apego en dichos territorios.
\end{abstract}

Palabras clave: Día de Muertos, comunalización/comunalidad, participación observante, repertorios interpretativos-culturales, memoria festiva, resistencia.

Abstract: This article compares the Day of the Dead celebration in the Flores Cemetery and neighborhoods of southwest Buenos Aires (Argentina) and the General Cemetery and Cerro Blanco in northern Santiago (Chile). In the former locale, those celebrating are Aymara, Qolla, and Quechua migrants from the central Andes; in the latter, they are urban mestizos who incorporate "Andean" practices as symbolic identity re-appropriation. From a perspective of an observant participant, we examine communalization/communality processes in the resignification of this celebration in both cities, focusing on interpretative-cultural repertoires used by different actors. We conclude that festive memories of resistance have been built by these practices, producing new feelings of belonging to each territory.

Key words: Day of the Dead, communalization/communality, observant participation, interpretative-cultural repertoires, festive memory, resistance.

* Pablo Mardones Charlone. Doctor en Antropología por la Universi-
dad de Buenos Aires, Argentina. Investigador en el Instituto de Estu-
dios Internacionales (INTE) de la Universidad Arturo Prat (UNAP),
Argentina. Temas de especialización: Migración, pueblos originarios,
Andes centrales, antropología audiovisual y fotografía etnográfica. Co-
rreo electrónico: mardones.pablo@gmail.com. ORCID: https:/orcid.
org/0000-0002-4490-1391
** Francisca Fernández. Doctora en Estudios Americanos por la Uni-
versidad de Santiago de Chile, Chile. Investigadora en el Instituto de
Enviado a dictamen: 11 de mayo de 2020

Aceptación: 4 de septiembre de 2020 0002-3286-1783

Estudios Avanzados (IDEA), de la Universidad de Santiago de Chile, Chile. Temas de especialización: Etnicidad y género, estudios andinos, conflictos socioambientales y peritaje antropológico. Correo electrónico: franciscadroguett@gmail.com. ORCID: https://orcid.org/0000- 


\section{Introducción}

L a ritualidad fúnebre ha sido entendida como parte constitutiva de los sujetos en tanto seres culturales ${ }^{1}$ y representa una de las ritualidades más significativas del devenir de la humanidad. ${ }^{2}$ Es así que la muerte se presenta como un permanente cuestionamiento ontológico de nuestras existencias, construyéndose continuidades esperanzadoras que permiten aliviar el fin de "un tipo" de existencia, a través de la realización de una serie de rituales mortuorios en que se vela, limpia, dialoga, despide y entierra al difunto.

Considerando experiencias previas de investigación de ambos autores, ${ }^{3}$ el propósito del presente artículo es realizar un análisis comparativo entre dos casos, uno en Buenos Aires y otro en Santiago de Chile, a partir de prácticas y elementos compartidos en ambos lados de la cordillera desde marcos de diferenciación propios, tanto en el terreno material como en el identitario (Mardones y Fernández, 2017).

Buenos Aires y Santiago son las capitales de dos de los Estados-nación latinoamericanos donde históricamente se ha invisibilizado lo amerindio mediante la instalación de la falsa idea de ciudades predominantemente "blancas". Mientras Buenos Aires fue imaginada como un enclave europeo (Grimson, 2012), en Santiago se consolidó un proceso de blanqueamiento imaginado (Bengoa, 2007).

Como metodología llevamos a cabo una investigación comparativa a partir de una participación observante en que nos constituimos como participantes emocionalmente comprometidos (Tedlock, 1991:151). Esta técnica metodológica, superadora de la observación participante, supone una intervención corporizada (Mora, 2013:31), un rol concreto y un compromiso social en el proceso que, a su vez, investigamos. A través de este proceso, en tanto músico para el caso argentino y como danzante para el chileno, reflexionamos sobre la tensión entre ser investigador social y sujeto-parte, y la centralidad de nuestro rol en la práctica etnográfica desde un enfoque colaborativo (Rappaport, 2007). Además, incorporamos algunas entrevistas abiertas a deudos y practicantes de la festividad.

Dos de los conceptos relevantes para dar cuenta de estos procesos son los de comunalización y comunalidad. A partir de que Brow (1990) acuñó el primer concepto, la comunalización refiere a cualquier patrón de comportamiento de promoción de un sentido de pertenencia y de dinámicas relacionales (Carsten, 2000), a partir de las cuales los grupos sociales crean vínculos entre sí más allá del parentesco directo. Comunalidad, por su parte, se define como una forma de entender el colectivismo indígena; es un componente estructural en que se articula la vida social (Maldonado, 2002), y que refuerza el sentido de pertenencia a una identidad cultural. Otra idea relevante para nuestra investigación es la de memoria festiva, la cual comprende el espacio festivo en tanto configuración de identidades colectivas, y sus usos políticos en la reformulación del pasado y la formación de presentes significativos (Fernández, 2018; Rossells, 2009; Scott, 2000). Esto implica entender la tradición como un bagaje cultural en constante transformación, según los usos y significados que las comunidades elaboran para sustentar la memoria histórica y la identidad (Aquino, 2003). En este contexto, la identidad se materializa en narrativas sobre el pasado (Castells, 2003), en las que las festividades resultan escenarios propicios para que las biografías particulares y la acción de rememorar de los sujetos se inscriban en una memoria colectiva (Isla, 2003).

El análisis comparativo de ambas ciudades está articulado desde el despliegue de los repertorios interpretativos y culturales que ellas comparten y en las que se diferencian. Entendemos por repertorios interpretativos el conjunto de símbolos y acciones desplegados en el marco de una identidad compartida (Fernández, 2018), y repertorios culturales como el conjunto de prácticas y discursos desde el cual los sujetos se sitúan a través de su experiencia de vida, actuando como marcos de referencia para los contextos de acción e interacción social, así como el conjunto de símbolos que configuran una identidad étnica. 


\section{Morir en los Andes y seguir perteneciendo a la comunidad}

En los Andes centrales ${ }^{4}$ el culto a los muertos es parte constitutiva del calendario festivo, en el cual la celebración, el espacio físico y social constituyen un todo (Aláez, 2001; Berg, 1989; Ochoa, 1974). Además de simbolizar el paso de la estación seca a la húmeda en el calendario, representa el traslado de las actividades de los vivos a los muertos (Bastien, 1996; Fernández, 2006).

Antiguamente los difuntos eran enterrados junto a sus viviendas con el fin de mantener estrechamente su vínculo familiar. En otras, fueron sepultados en wak'as o kalasallas (monolitos sagrados), espacios ceremoniales en los que los deudos podían rendirles culto (Rivera Cusicanqui, 2010). En contexto migratorio, las familias y comunidades dan vida a esta conmemoración reconstruyendo su pleitesía a los muertos a través de los conocimientos y prácticas de sus ancestros, mediante la generación de altares en tanto sitios de memoria donde los difuntos son recordados en el marco de la festividad.

El l de noviembre, al medio día, marca el inicio de la fiesta, cuando los muertos llegan al lugar de los vivos. El festejo se lleva a cabo en el ámbito privado, y son los músicos y los resiris (rezadores) quienes los reciben acompañados de la familia nuclear, madrinas y padrinos. Para acogerlos se prepara un altar doméstico de tres niveles. En los dos primeros se ubican objetos sagrados, velas encendidas y panes en forma de animales, escaleras, estrellas, lunas y soles. En el nivel inferior, el más importante, llamado la mesa del difunto, se colocan alimentos y bebidas que se han preparado para su alma. El 2 de noviembre los deudos reciben a los muertos en el cementerio, donde participa la familia extendida y, en general, toda la comunidad. La mesa se desmonta del espacio privado y vuelve a montarse en el público. La comida no debe regresar a la casa, pues hacerlo representaría un mal augurio para el deudo.

La representación del alma del difunto se manifiesta a través del t'antawawa (pan de bebé) (Fernández, 1998). Asimismo, con el fin de que las almas viajen al Wiñay Marka (pueblo o ciudad eterna), se confeccionan —con trigo al igual que los t'antawawa — caballos, llamas, lunas, estrellas y soles.

En los Andes centrales morir constituye un fenómeno privilegiado de las representaciones colectivas (Hidalgo, 2011); en ellas se asume que los difuntos garantizan prosperidad y bienestar a los vivos (Berg, 1989). Es por eso que la comunidad necesita que "los que partieron" sigan perteneciendo. Al ser parte de una misma comunalización/comunalidad, orientada por iguales sentidos de pertenencia, los muertos no pueden desvincularse de la comunidad. Se puede morir, pero no por ello dejar los compromisos vinculantes (Rengifo, 1996). Según la creencia, solo luego de tres años la comunidad permite que el difunto se descomunalice. Esto responde, justamente, a la relevancia de las dinámicas de comunalización en los Andes centrales, las cuales superan los vínculos de parentesco directo e incluyen a toda la comunidad (Brow, 1990). Durante ese lapso, las dinámicas relacionales y de comunalización incorporan la interrelación, de tal modo que el muerto tiene agencia en el mundo de los vivos (Rivera Cusicanqui, 2010).

\section{Comunalización mortuoria "panandina" festiva en el cementerio de Flores y barrios del suroeste de la Ciudad de Buenos Aires}

En Buenos Aires, personas y comunidades de diferentes territorios de los Andes centrales celebran el Día de los Muertos. Estas mujeres y hombres provienen de los departamentos de Cochabamba, Potosí, La Paz y Oruro, en Bolivia; del de Puno, en Perú, y de provincias del Noroeste Argentino (NOA), principalmente Jujuy. Igualmente, es celebrado por hijos y nietos de estas y estos migrantes nacidos en Buenos Aires.

Sus formas de festejo son disímiles, aunque emparentadas, entrelazando prácticas "panandinas" en un proceso cambiante y marcado de nuevas tensiones y acuerdos.

Me acuerdo una vez una mujer discutía con Juan José, un cochabambino: —no pero allá se hace así [...]—. Luego de rozar un poco llegaron a acuerdo. Orígenes diferentes que aquí comparten una misma práctica y 
tratan de imponer lo que ellos conocían, lo que lleva a generar una forma diferente producto de esas diferencias. Más elementos que se van incorporando de acá. Acá en una mesa de difunto aparece el mate, por ejemplo (entrevista a Jorge Vargas, Buenos Aires, 14 de agosto de 2014).

Los Andes centrales, aunque con estrechos vínculos y dinámicas relacionales, son diversos. En este contexto, prácticas comunes en un nuevo espacio de arribo forjan procesos de comunalización entre personas y comunidades. ¿Qué implica para mujeres y hombres de diferentes orígenes enterrar a sus muertos lejos de donde nacieron? En las comunidades rurales no hay necesidad de evidenciar diferencias. En la ciudad, en cambio, más incluso en grandes metrópolis, se vuelve necesario marcar ciertas particularidades. Aparecen iconos diferenciantes, como es el caso de fotografías y el nombre del fallecido en las mesas rituales. La memoria social (Isla, 2003) de este festejo se ha conformado a través de disputas y consensos con los variopintos orígenes, en que las particularidades adquieren sentidos de pertenencia comunalizables (Brow, 1990). Así, las distintas adscripciones incorporadas en el contexto migratorio interactúan en un inter-juego de sentido: "andino", "indígena", "boliviano", "norteño", con aquellas de origen específico por región, comunidad o etnia (ver Foto l).

El Día de los Muertos, por parte de migrantes indígenas en Buenos Aires, construye territorialidad, sentido de pertenencia y dinámicas relacionales (Carsten, 2000), lo que reproduce sus prácticas vitales (Giménez, 2001) a partir de la memoria (Fernández, 2018) y el vínculo con el endo y el exogrupo (porteños, bonaerenses). ${ }^{5}$ Esta condición genera novedosos sentidos de apego en el nuevo espacio de arribo.

Según Jorge Vargas, ${ }^{6}$ el festejo a los muertos en el porteño cementerio de Flores, por parte de estos migrantes, se volvió práctica comunitaria y masiva en la década de 1990. Según su explicación, este cambio respondería a la consolidación de la migración boliviana en la ciudad y, con ello, al paulatino fallecimiento de migrantes de aquel país. Para que esta celebración en Flores se volviera masiva operaron heterogéneas redes que incorporaron diversas costumbres, prácticas y saberes. Fueron las personas pertenecientes a hogares donde se continuaron actualizando prácticas heredadas, sumadas a la preeminencia de migrantes más memoriosos o aquellos de reciente arribo, quienes revitalizaron la tradicionalidad de ciertos ritos (Mardones, 2020).

Debido a que se trata de un día no feriado y a que los horarios de apertura y cierre son acotados, sumado al atochamiento en el ingreso y a las condiciones laborales y de traslado de los deudos, en el cementerio de Flores esta celebración se desarrolla de forma más corta. Se trata de algunas horas entre el mediodía (cuando según la creencia las almas llegan al camposanto) y la retirada de los deudos, impulsada por el hostigamiento policial y de funcionarios realizado con mucha anterioridad al cierre del cementerio (Canelo, 2006, 2013). ${ }^{\text {? }}$

En Buenos Aires, un mes antes del Día de Muertos los deudos se movilizan para preparar y comprar lo necesario con el dinero que han ahorrado. Los comerciantes ofrecen diversos productos para la ejecución del rito: alcohol, t'antawawas, hoja de coca, incienso y copal para la pawa, ${ }^{8}$ serpentina para ch'allar, ${ }^{9}$ flores, confites, banderines, entre otros (ver Foto 2).

Dos semanas antes comencé a hacer las compras. Son muchas cosas que hay que alistar. Además los precios suben en Liniers. ${ }^{10}$ Compré todo lo necesario para hacer las t'antawawas, pa' hacer la chicha, hoja de coca. ¿Qué más? Otras cosas para decorar la mesa también (entrevista a Elizabeth Oviedo, Buenos Aires, 7 de julio de 2010). ${ }^{11}$

Los procesos de comunalización generados entre aymara, qolla y quechua radicados en Buenos Aires suponen la transformación de tradiciones heredadas y estructuradas desde experiencias migratorias individuales y colectivas, asumiendo nuevas dinámicas basadas en la memoria y los afectos (Maldonado, 2002). El lugar fundamental de estas presunciones se constituye en la idea cardinal del rito en el cual se muere, pero no se cortan los vínculos comunitarios (Rengifo, 1996). De esta forma, la celebración de este rito en Buenos Aires se presenta como una versión renovada de la celebración 
compartida por sentidos y prácticas de una vasta región en complementariedad con otras nuevas adaptadas a los condicionamientos metropolitanos y resignificadas por la experiencia transmigratoria.

Con el propósito de compartir diferencias y similitudes entre vecinos, así como con la idea de que los venidos desde muy niños o nacidos en destino incorporen el know how comunitario, la significación de tiempos, roles y elementos es transmitida de forma oral y como ejercicio de identificación. Los aprendizajes incorporados constituyen mecanismos de conservación a partir de sus nuevas trayectorias. Se trata de formas de recontextualizar las subjetividades afectivas que los conforman, reorganizando los sentidos de un endogrupo (bolivianos, peruanos, argentinos nordesteños) y de un exogrupo (porteños y bonaerenses).

Retomando la descripción de la festividad, el 1 de noviembre las actividades se centran en el ámbito privado, en general en la vivienda del difunto y sus familiares, tal como sucede en los Andes centrales. En este espacio, familiares, vecinos y amigos elaboran una mesa. Se trata de un altar que suele estar constituido por tres pisos, acorde a los tres niveles cosmogónicos de los Andes centrales (hanan o alak pacha, aka pacha y urin o manka pacha).

A veces, para evitar complejidades, disponen solo dos pisos. Lo más común es ubicar una mesa pequeña sobre una más grande, ambas cubiertas por una tela negra, generando así dos niveles. La noche del 1 al 2 de noviembre, las familias con mesas de difuntos son visitadas y se bebe cerveza u otro líquido. Los familiares y amigos rezan y cuentan historias y anécdotas de ellos. En su parte más alta, para que el difunto viaje, se colocan las escaleras y los caballos, además de los símbolos estelares. En el piso intermedio, los familiares disponen los elementos propios del difunto, ya que este nivel simboliza el mundo de los vivos (akapacha) y el presente. En este nivel, igualmente, colocan la bebida que a él le gustaba, además de elementos que le agradaban y usos culturales que fue adquiriendo en destino, tales como la camiseta de su equipo de fútbol argentino o el mate, si es que tomaba. Finalmente, en el nivel inferior, los cercanos disponen t'antawawas y los platos de comida. De esta forma, comidas típicas del lugar de origen conviven con aquellas propias de la gastronomía porteña, como pastas y pizzas (ver Foto 3).

Como se observa, los repertorios interpretativos en el contexto migratorio, particularmente en una metrópolis, implican una personificación de la mesa que no era necesaria en los lugares de origen. Así, aparecen las fotografías de los difuntos, además de postales de sus pueblos o ciudades de origen. En Buenos Aires, como consecuencia de los procesos de resignificación indígena que se experimentan desde la década de 1990 (Mardones, 2016, 2019), muchas veces las mesas están acompañadas de chakanas ${ }^{12}$ y whipalas. La preparación de las mesas constituye una práctica de objetivación de las historias personales en la que se conjuga la memoria de sus orígenes con experiencias migratorias familiares y del difunto: "Mi marido era orgulloso de su origen orureño, por eso le pusimos el escudo del San José [equipo de fútbol de la ciudad de Oruro]" (entrevista a Lidia Remonte, Buenos Aires, 6 de agosto de 2010); "Pusimos las fotos de varios familiares que eran cercanos, algunos están en Cochabamba, otros están aquí con nosotros. Para él todos eran muy queridos" (entrevista a Gervasio Cortés, 2009).

Este proceso de objetivación resulta crucial en Buenos Aires; aquí las mesas o altares, como expresiones de memoria (Fernández, 2018), devinieron soporte para poner en común la experiencia migratoria dentro de los marcos interpretativos de una tradición compartida.

El 2 de noviembre en el cementerio de Flores de Buenos Aires - de forma similar a como sucede en el ámbito rural (Berg 1989; Ferraro, 2004) - se celebra en clave ritual comunitaria. Este día, las familias deshacen la mesa armada el día l para trasladarla con sus elementos al camposanto. Además de a los familiares y cercanos que, por lo general, pasaron la víspera del 1 con ellos (particularmente los tres primeros años), se hace una invitación a la familia extensa, amigos, conocidos y vecinos. Desde antes del mediodía van llegando lentamente los deudos, sobre todo mujeres. Según la tradición, el alma llega al cementerio al mediodía del 2 de noviembre, pero en la Argentina, a diferencia de la mayoría de los países latinoamericanos, no es feriado, ${ }^{13}$ 
por lo que los deudos, muchos trabajadores empleados, pueden arribar en la medida que logran conseguir permisos en sus trabajos para ausentarse.

$\mathrm{Al}$ igual que sucede en el ámbito privado de cada familia, en el cementerio de Flores las mesas se arman con flores, guirnaldas, cigarrillos y velas para llamar a las almas. La presencia de alcohol está condicionada a que los familiares logren sortear el ingreso al camposanto, lo que se ha dificultado desde que este festejo se masificó en Flores (Canelo, 2013). Lo mismo sucede con la coca, condicionada a los controles de ingreso a la Argentina.

Antes de finalizar la jornada, todos los alimentos de la mesa deben repartirse, ya que es mala fortuna regresar con ellos al hogar. Como el cementerio cierra a las seis de la tarde, y mucho tiempo antes guardias y policías comienzan a instar a las personas a que se retiren, es sumamente difícil lograr esta meta. Muchas veces nos tocó ver que, hacia el final y de forma ansiosa y acelerada, los deudos se apresuraban a entregar toda la comida y la bebida disponibles.

En las experiencias que el coautor de este artículo tuvo durante los primeros años como músico, pudo apreciar la relevancia de la música y de sus intérpretes, quienes tienen una gran responsabilidad al ser contratados y requeridos de forma constante por los deudos. En el cementerio de Flores, ellos se acercan y van solicitando el servicio musical, el cual consiste en interpretar algunos temas junto a la tumba. Con posterioridad, los familiares pagan un precio previamente establecido. Principalmente se oyen melodías de tarkeadas y pinkillos, flautas para llamar a las lluvias propias de esta época en los Andes centrales. También se escuchan aerófonos de bronce, especialmente trompetas, junto a bombos de banda, así como zampoñas, pese a no ser propios de temporada pluvial (ver Foto 4).

Desde que esta fiesta se celebra masivamente en el cementerio de Flores, emergieron otros sentidos que fueron produciendo interpretaciones rituales inscritas en experiencias urbanas y migratorias. Estas recreaciones se aprecian en las mesas, el 1 de noviembre en el ámbito privado a través del armado, y el día 2 en el público. Son confeccionadas como una representación de experiencias migratorias y dinámicas de identifica- ción que oscilan entre los lenguajes del cristianismo y de la cosmovisión centroandina, de los ciclos rurales y las marcaciones urbanas, así como de los lugares de origen y los sitios de habitación actual.

Frente al deseo de establecer nuevos sentidos de pertenencia como migrantes, la masificación reciente de este rito en Flores representa un logro colectivo: el despliegue público de una apropiación espacial realizada de acuerdo con marcos significativos de interpretación. En este proceso se articulan dinámicas de comunalización entre personas de diversas comunidades de los Andes centrales que no tenían o tienen un vínculo de parentesco directo. Fue aquí, en Buenos Aires, donde sus orígenes tomaron sentido desde sus prácticas comunes. Así, constituye un encuentro en que personas conocidas y desconocidas entre sí, y con trayectorias heterogéneas, se cruzan espontáneamente en un sitio común de apego, objetivando un determinado tipo de conexión que exterioriza los vínculos con sus ancestros.

\section{Reapropiación cultural y etnificación "andina" en el Día de Muertos en el Cementerio General y Cerro Blanco de Santiago}

En la ciudad de Santiago de Chile, a partir de la década de 1980 comenzó un flujo migratorio aymara desde el altiplano, fundamentalmente de cultores de danza y música, que conformaron las primeras agrupaciones artístico-culturales y organizaciones indígenas - Coordinadora Nacional Indianista (CONACIN), Inti Marka-. Este proceso se intensificó con la masiva salida de población aymara y quechua desde Bolivia y Perú (Taypi Aru, 2011).

Esta dinámica migratoria y organizativa - junto a la realización de una serie de investigaciones sobre la ocupación del Tawantinsuyu (el incanato) en el valle central chileno (Bustamante, 2006; Fernández, 2018; Stehberg y Sotomayor, 2012) - posiciona la ciudad de Santiago desde una relación vincular identitaria con los Andes centrales, que la coautora del presente escrito identifica como "etnificación andina", en que mediante la reapropiación de elementos culturales del mundo rural y urbano aymara-quechua, provenientes del norte 
de Argentina y Chile, así como de Bolivia y Perú, se han configurado memorias e identidades de resistencia en sujetos, que sin necesariamente autorreconocerse como indígenas se autoafirman como "andinos" por el hecho de habitar en una territorialidad reconocida como tal (Fernández, 2018). En este marco se reivindican prácticas culturales-espirituales como el ayni (reciprocidad), el apthapi (comida comunitaria), la pawa (mesa ceremonial), la ch'alla (bendecir rociando alcohol) y la veneración a la Pachamama, así como la realización de festividades como la Anata (carnaval "andino"), la Chakana (cruz de mayo), el MachaqMara-Inti Raymi (festividad del sol asociada al año nuevo indígena) y la conmemoración del Día de Muertos, el Wiñay Pacha.

Ell de noviembre, Día de Todos los Santos en Chile, se ha establecido oficialmente como el día de celebración a los muertos. Específicamente en el Cementerio General de Santiago, en este día feriado miles de personas visitan a sus muertos o también a personajes públicos, o simplemente realizan un paseo por el sector desde un afán más bien turístico (Fernández y Michel, 2014b). Es en este marco cuando durante el año 2009 algunos ex integrantes de la comunidad de músicos y danzantes Wiñay Katari, e integrantes del colectivo de Danzas Andinas Quillahuaira, decidieron conmemorar la fiesta de difuntos, apodada por las colectividades de entonces como Wiñay Pacha. Así, esta se realizó a través de un circuito festivo al son de los aerófonos de madera tarkas (propios de esta época en los Andes centrales), y se sumó posteriormente la agrupación de danza Sariri.

Ese mismo año, el colectivo Quillahuaira junto al colectivo Tinkus Legua decidieron celebrar la fiesta de difuntos como una forma de desplazar la noche de Halloween, reivindicando prácticas culturales aymaraquechua a partir de su condición mestiza urbana. Con tal fin, se decidió realizar un pasacalle por el barrio Brasil y Yungay, zonas ubicadas en el centro de la capital, la noche del 31 de octubre; se nombró la festividad como Wiñay Pacha. La elección del nombre se fundamenta en una sistematización bibliográfica sobre la muerte en los Andes centrales a partir del trabajo de Fernando Huanacuni Mamani, aymara perteneciente a una agrupación boliviana llamada Comunidad Sariri. Este autor conceptualizó la idea de la muerte como un tiempo y espacio eterno, mediante el cual se genera un reencuentro entre la tierra y el cielo que es festejado (Fernández, 2018; Fernández y Michel, 2014a).

\begin{abstract}
Nosotros quisimos conmemorar de otra forma la muerte, pero sobre todo dar cuenta de que existían diversas formas de recordar a los muertos, más allá de Halloween. Nos pusimos a investigar y es ahí que una de nuestras compas se encuentra con el concepto de Wiñay Pacha. Entonces decidimos llamar así a la festividad, pero entendiendo que íbamos a recrear una fiesta "andina" pero mestiza y urbana (entrevista a Tania Osses, 10 de agosto de 2011, Santiago). ${ }^{14}$
\end{abstract}

La festividad de Wiñay Pacha adquiere la dinámica de alferazgo, modalidad en la cual cada año una agrupación artística se hace cargo de su realización. Así, en su respectivo turno fueron alféreces Quillahuaira, Tinkus Legua, Alwe Kusi, Kuyukusi y Santiago Marka. Esta última, en el año 2013, decidió finalizar con la lógica de alferazgo para posicionar más bien la conmemoración mediante la realización de mesas ceremoniales en espacios sagrados, como el cerro Chena, considerado una huaca (sitio sagrado) tanto por danzantes y músicos como por varios investigadores (Fernández, 2018). Con ello inició la diversificación de conmemoraciones en Santiago (Fernández y Michel, 2014a) (ver Foto 5).

Respecto de la celebración "andina" a los muertos en el Cementerio General, esta se basa en un circuito de visitas a distintas tumbas, comenzando en la entrada principal del cementerio o por el Cementerio Católico que se ubica al frente, por avenida Recoleta. Se realizan dos tipos de visitas: a difuntos danzantes y músicos, y a figuras emblemáticas de la cultura popular chilena, como Violeta Parra, y de la resistencia a la dictadura cívico militar de Pinochet, como Miguel Henríquez y Víctor Jara. El recorrido finaliza en el Memorial de Detenidos Desaparecidos y Ejecutados Políticos, en una de las salidas hacia avenida Recoleta.

La festividad, sin embargo, se inicia unos días antes, con la preparación de las mesas ceremoniales, la música y la danza. Algunos participantes se reúnen a ensayar, 
a elaborar panes llamados t'antawawas o a comprar los productos que se consumirán.

Quienes participan son mayoritariamente sujetos mestizos urbanos sin vínculos parentales indígenas —en general músicos y danzantes- que se autoidentifican como "andinos", lo que remite al proceso de etnificación "andina" anteriormente nombrada. También participan, en menor grado, sujetos aymara y mapuche. A pesar de esto, todos los participantes visten prendas indígenas.

En cada tumba, sitio o memorial se realizan mesas ceremoniales que cuentan con diversos productos, algunos propios de los Andes centrales, otros de Santiago. Se interpreta tarka en forma de pasacalle (desplazamiento tocando desde un punto A a uno B). En las mesas o apxätas ${ }^{15}$ está presente la hoja de coca, serpentina, alcohol, fruta, t'antawawa, una foto del difunto, wiphala, y en algunas ocasiones chapitas o algún otro objeto particular. La base de la mesa es un aguayo. ${ }^{16}$ En cada tumba los familiares o amistades presentan al fallecido, y en caso de ser figuras públicas se realiza una breve reseña de su labor y legado. Luego suenan las tarkas, se ch'alla con cerveza, hojas de coca, mixtura, serpentinas y dulces.

Uno de los puntos a destacar es el recorrido que realizamos en el cementerio, donde presentamos a nuestros muertos, los cercanos o quienes nos parecen relevantes para nuestra memoria. La gente se nos acerca, nos pregunta sobre lo que estamos realizando. Quizás nos miran con extrañeza pero también hay emoción, se dan cuenta de la ritualidad que acompaña la música de las tarkas (entrevista a Marcelo Cornejo. Santiago, 2 de octubre de 2012). ${ }^{17}$

Otro hito relevante es la visita, alrededor del mediodía, al Patio 29, lugar emblemático en que fueron enterrados cuerpos sin identificar de detenidos desaparecidos y ejecutados políticos durante la dictadura cívico militar chilena. En este espacio, en el cual se encuentra una serie de cruces, pasa la tarkeada, dirigiéndose luego a una plataforma ubicada al frente, donde al finalizar se lleva a cabo un apthapi sobre una serie de aguayos en que se deposita la comida, bebida y coca a compartir (ver Foto 6).

Como se señaló anteriormente, el recorrido finaliza con la visita al Memorial de los Detenidos Desaparecidos y Ejecutados Políticos, donde todos danzan al son de las tarkas, además de lanzar serpentina y en algunas ocasiones petardos (Fernández y Michel, 2014a). En diversas oportunidades se acercan familiares de personas que aparecen en el memorial expresando gratitud por el acto. En tanto, la celebración de la fiesta de muertos en el Cerro Blanco se asocia al término del sistema de alferazgo del Wiñay Pacha, en que las colectividades se trasladan de sus localidades o viviendas para realizar la festividad. Aunque su relevancia particular constituye la elaboración de un altar permanente con las cenizas de tres difuntos asociados a las organizaciones de Cerro Blanco.

El Cerro Blanco — conocido a través de diversos documentos coloniales como cerro o Apu Huechuraba- se ubica en la comuna de Recoleta, siendo, según Massone (1978), un lugar de tránsito y vía de comunicación de poblaciones indígenas del valle central chileno. Aquí se encontraron instrumentos líticos y cerámica de los periodos culturales Molle y Aconcagua Salmón, además de ser la puerta de entrada de la ocupación del Tawantinsuyu. Considerando su pasado y su uso actual, la CONACIN, que tuvo su origen en 1991 en la ciudad de Santiago y está compuesta por una veintena de organizaciones sociales, reivindica el espacio como un lugar patrimonial indígena y mestizo que es ocupado hace veinte años con ese fin (Fernández, 2018).

La celebración de muertos se realiza entre el 31 de octubre y el 1 de noviembre, aunque la festividad en sí comienza con los preparativos, sobre todo con la realización de t'antawawas y la ornamentación de la Casa Andina y del Altar de Difuntos, ambos ubicados en la llamada zona 2 del cerro. Lo primero que se realiza es la colocación de los altares en que se ubicarán las ofrendas para los muertos. Algunas mesas son compartidas por varios muertos, otras son individuales. En cada altar se ponen diversos productos, algunos están asociados a los gustos del difunto y otros son característicos de las mesas ceremoniales de los Andes centrales, como hoja 
de coca, serpentina, alcohol, t'antawawas y velas, entre otros. Las mesas se colocan de manera circular en el patio de la zona 2, con el propósito de que los difuntos interactúen entre sí y con los deudos (ver Foto 7).

Luego de finalizada la preparación de los altares, comienza la música con la ejecución de tarkeadas y pinkilladas, y de manera particular lakitas, debido a la relevancia que poseen estos conjuntos en el lugar en tanto partícipes de CONACIN. Se visita cada altar, cuando los deudos aprovechan para hablar sobre el difunto, ch'allándose cada mesa.

De las cosas potentes de la fiesta está el saludo que se realiza a cada difunto, donde familiares o amigos hablan de él. Son los músicos quienes inician esto. Es como si realmente estuviesen ahí, en el mismo Cerro Blanco. Da emoción ver cómo en la ciudad se realizan cosas como estas que me recuerdan a mi querido norte, cuando vamos a visitar a nuestros muertos (entrevista a José "Patara" Segovia, Santiago, 16 de marzo de 2015)..$^{18}$

Luego de eso se da inicio al apthapi, compuesto por una serie de mesas con bebidas y comidas. Pasada la medianoche comienza el consumo de los productos de cada altar, bajo la idea de que a través de los deudos los difuntos comen y celebran. La música y la danza duran hasta el amanecer, cuando se sirve una sopa al finalizar la celebración. Luego de ello algunos participantes se trasladan al Cementerio General para festejar junto a la tarkeada antes citada.

Esta celebración en Santiago de Chile da cuenta de un proceso de andinización y reapropiación simbólica identitaria emprendido desde colectividades autodenominadas de música y danza andina, las cuales, en la mayoría de los casos, no cuentan con miembros indígenas. Lo interesante es que esta festividad se posiciona en el calendario festivo local desde un proceso de etnificación producido por individuos y colectividades mestizas, lo que constituye una forma de generar un vínculo con los muertos a partir de repertorios interpretativos aymara y quechua, además de crear nuevos referentes desde una experiencia urbana (ver Foto 8).

\section{El festejo de muertos: comunalización/ comunalidad y memoria festiva}

La concepción de ser parte de una comunidad remite a una forma histórica que promueve el sentido de un ser-estar juntos (Rengifo, 1996), un sentimiento de pertenencia resignificado en el marco de lazos de solidaridad y de identidad compartida entre los miembros de un grupo. A través de este proceso denominado comunalización (Brow, 1990), los protagonistas reconstruyen una nueva versión de su pasado basada en sus orígenes comunes. Además, a través de diversas formas de comunalización, los muertos, junto a sus respectivos deudos, mantienen sus compromisos comunitarios más allá de la vida y la muerte.

Otro término que hace referencia a la idea de comunidad es el de comunalidad, que corresponde a una forma de nombrar y entender el colectivismo indígena $y$ es un componente estructural de diversos pueblos. Es la lógica con la que funciona la estructura social y la forma en que se define y articula la vida social (Maldonado, 2002). A través de la comunalidad los indígenas expresan su voluntad de ser parte de la comunidad, reforzando su sentido de pertenencia a una identidad cultural, como parte real y simbólica. Se puede llegar a ser monolingüe en español, no usar la vestimenta tradicional, dejar de practicar rituales y abandonar la comunidad territorial de origen, pero se mantiene la pertenencia comunitaria.

Quienes han migrado no pueden trabajar cotidianamente en la comunidad, pese a lo cual pueden participan a través de varios mecanismos: adquiriendo cargos políticos, encargando a otros comunarios ciertas tareas o servicios, enviando dinero para las fiestas, entre otras. En síntesis, la comunidad los sigue identificando como sus integrantes (Maldonado, 2002).

Es muy importante señalar que la comunalidad no es exclusiva de los pueblos indígenas, se encuentra presente también en numerosas comunidades rurales y urbanas no indígenas que se rigen por la reciprocidad y la participación en cargos, asambleas, trabajos colectivos y, en algunos casos, bajo una territorialidad definida en términos comunales. 
Con base en estas concepciones de comunalización/ comunalidad, comprendemos y situamos el Día de los Muertos como una festividad que reconstruye memoria festiva en la cual la formación, la continuidad y el sentido de una colectividad recrean y resignifican su pasado con el objetivo de proyectarse identitariamente, y con ello se da forma a una experiencia histórica. Este proceso implica que la memoria sea concebida como soporte principal de un discurso contrahegemónico, mediante el cual las representaciones del pasado son utilizadas para formar identidades colectivas y alianzas que resultan cruciales en la construcción de la identidad étnica y en la formación de proyectos políticos (Aquino, 2003).

En los Andes centrales las memorias festivas se inscriben en nociones tanto temporales como espaciales. Las festividades como, por ejemplo, la del Día de los Muertos son espacios en los que la memoria enfatiza hechos del pasado que otorgan el carácter de símbolos en las prácticas del presente y son invocados como una forma política de identidad a través de la fijación de trazos de su tradición. Asimismo, en términos espaciales, la memoria produce un transitar entre sitios, lugares sagrados, constituyendo rituales celebratorios anclados en dimensiones físicas, geográficas y, por ende, en relaciones sociales concretas (Isla, 2003).

El Día de los Muertos, tanto en Buenos Aires como en Santiago, da cuenta de la configuración de identidades, memorias y estéticas de resistencia, a través de la resignificación, la reelaboración y la apropiación de "lo andino" mediante la articulación de lo festivo y lo político. En este quehacer se movilizan memorias históricas que construyen identidades alternativas al discurso monocultural y proponen mecanismos contrahomogeneizantes que reivindican y recrean nuevas territorialidades desde lo conmemorativo y ritual (Fernández, 2018). En la realización de esta festividad, en ambos lados de la cordillera se despliega un conjunto de acciones y repertorios interpretativos, tales como ch'allar, armar mesas ceremoniales y adquirir roles, que reafirman el sentido de pertenencia a una identidad colectiva propia de los Andes centrales y a su vez urbana.

Actualmente, además de comunalizar prácticas e identidades que cruzan trayectorias heterogéneas en un sitio común de apego, en Buenos Aires, migrantes de distintos lugares de los Andes centrales reconocen su pertenencia identitaria como indígenas en el nuevo contexto de origen, la cual, en muchos casos, no estaba presente antes de migrar (Mardones, 2019, 2020). En Santiago, por su parte, es posible constituirse como "andino" sin necesariamente autoadscribirse indígena desde la resignificación identitaria de una andinización del mestizo urbano a través de la fusión y yuxtaposición de diversos contenidos simbólico-cultural-políticos (Fernández y Michel, 2014a, 2014b; Fernández, 2018). Tanto en Buenos Aires como en Santiago la fiesta se comunaliza, reproduciéndose la memoria de forma festiva.

\section{A modo de cierre. Las negociaciones del "ser-estar juntos" entre migrantes y nativos en Buenos Aires y Santiago de Chile}

Describiendo y analizando comparativamente dinámicas identitarias y metadiscursivas de un lado y otro de la cordillera (Mardones y Fernández, 2017), en este artículo pretendimos dar cuenta del desarrollo en los últimos años de algunos procesos simbólicos acontecidos en la festividad del Día de los Muertos, en los que se han observado mecanismos de (re)etnificación que han ido reflejando continuidades, tensiones y ambigüedades respecto a sus referentes de origen en los Andes centrales. Aquí, nuestras propias trayectorias biográficas como músico y danzante orientaron las decisiones metodológicas e influyeron en la forma en la cual el "campo" se fue construyendo. De esta forma, enfoques y técnicas resignificaron las marcas identitarias con las que nos presentamos en el "campo". Así, mientras acompañábamos a deudos y difuntos, se fueron entramando múltiples posicionamientos y formas de circular, ambas desde la principal premisa que identificamos: los vínculos relacionales comunitarios no se pierden cuando uno muere.

En las dos ciudades esta celebración se manifiesta como uno de los principales ritos en el proceso de indigenización/andinización que experimentan. Mientras en Buenos Aires se evidencia la reproducción y visibilización de costumbres indígenas-migrantes, en Santiago 
se constituye como una de las actividades principales en el calendario "andino-mestizo", en el cual se resignifican prácticas que, inicialmente vistas como ajenas, se fueron incorporando.

Los rituales que se desarrollan durante la celebración mortuoria en Buenos Aires y Santiago ejercitan la convivencia comunitaria mediante la revalorización de valores propios de los Andes centrales, resaltando, en la primera ciudad, la importancia vital que tiene la forma en que este colectivo migrante reconstruye y resignifica eventos culturales de sus orígenes, y en la segunda, mediante su apropiación e interpretación. En ambos casos se ejercen relaciones de compadrazgo/ padrinazgo, de ayni (reciprocidad) y de compromiso colectivo que permiten la realización de este culto dándole sentido comunitario.

La comunalidad del muerto adquiere una centralidad simbólica en la celebración, tanto en los Andes centrales como en el contexto migratorio. El hecho de que la muerte no separe a los difuntos de la comunidad y no implique un corte con los lazos de pertenencia presupone que ellos y ellas continúan teniendo responsabilidades y compromisos en vinculación con los vivos. Paralelamente, a través del rol y compromiso de la familia ritual con la familia de los muertos se generan lazos de comunalización que van más allá de aquellos de parentesco directo. El festejo de los difuntos, a través del lenguaje parental, es también una instancia metadiscursiva privilegiada para repensar colectivamente la experiencia de un ser-estar juntos. Desde esta perspectiva, el ritual del Día de los Muertos es una negociación colectiva tanto en Buenos Aires como en Santiago, puesto que ahora es "aquí" donde se recrean y confirman los lazos entre los muertos y los vivos, incluyendo parientes, amigos y vecinos.

Las prácticas que constituyen el ritual del Día de los Muertos son sentidas como propias y heredadas, aunque su importancia en la cotidianeidad también es producto de las resignificaciones que estas adquieren a través de los cruces de movilidades que constituyen el espacio migratorio urbano, en el caso argentino, o mediante la reapropiación de elementos cosmogónicos aymara-quechua en el chileno. En este contexto, los mecanismos de relacionalidad entre vivos y muertos permiten el potenciamiento de una memoria social comunitaria festiva que vincula de forma afectiva el presente con el pasado, generando comunalización/ comunalidad en las trayectorias migratorias de quienes están vivos y de quienes ya no lo están. Es a partir de estos viajes y los respectivos retornos de los muertos, en los que se construye territorialidad, cuando se producen —esta vez en un nuevo lugar- nuevos sentidos de pertenencia.

\section{Notas}

${ }^{1}$ Ambos autores agradecen a sus respectivos proyectos, a través de los cuales fue posible la financiación del presente artículo. Pablo Mardones: investigador responsable del proyecto Fondecyt núm. 3180333 “Etnificación, etnogénesis, comunalización y procesos fronterizos en las fiestas tradicionales aymara de la Región de Tarapacá”, Argentina. Francisca Fernández: Investigadora Responsable (IR) del proyecto Fondecyt núm. 11170090 "Pluralismo jurídico y derecho indígena en Chile: reflexiones y contribuciones desde el sistema normativo aymara".

${ }^{2}$ Ver, por ejemplo: Berg (1989), Fernández (1998), Ferraro (2004), Hidalgo (2011), Kauffman (2010), Ochoa (1974).

${ }^{3}$ Ver, por ejemplo: Fernández (2018), Fernández y Michel (2014a, 2014b), Mardones $(2016,2020)$ y Mardones y Fernández (2017).

${ }^{4}$ Pese a que la mayoría de la bibliografía se refiere a la celebración de comunidades aymara, debido a que los pueblos de los Andes centrales llevan a cabo un complejo de prácticas que los emparentan, estas son asimilables a la celebración de los quechua, qolla y de otros pueblos de la denominada "cultura andina".

${ }^{5}$ Porteño es el gentilicio de los oriundos de la Ciudad Autónoma de Buenos Aires, mientras que bonaerense es el de aquellos nacidos en la provincia de Buenos Aires.

${ }^{6}$ Nacido en Cochabamba y radicado en el barrio Charrúa en Buenos Aires, investigador y miembro de la cooperativa Copamuco Ltda. y del canal 31 de la villa 31. Entrevista realizada en Buenos Aires, 14 de agosto de 2014. 
${ }^{7}$ En Flores, con el objetivo de evitar que la aglomeración no permita el cierre del cementerio a la hora convenida, guardias y policías comienzan a solicitar el retiro - generalmente de forma agresiva - mucho tiempo antes del cierre. En este procedimiento se evidencian dinámicas de xenofobia y racismo institucional.

${ }^{8}$ Mesa ceremonial a través de la cual se pide bendición y se solicita protección a los espíritus.

${ }^{9}$ Bendecir a través del rocío de alcohol a objetos, sujetos, animales y entidades espirituales.

${ }^{10}$ Mercado más importante de la colectividad boliviana y centroandina, en general, de Buenos Aires.

${ }^{11}$ Migrante de origen quechua del departamento de Cochabamba, Bolivia.

${ }^{12}$ Icono sagrado de los Andes centrales, representado por las cuatro estrellas que forman la constelación de la cruz del sur. Significa "cuatro escaleras" o "cuatro puentes" en aymara y quechua, respectivamente, y ha sido traducida como cruz andina (Milla, 1983).

${ }^{13}$ Se retiró junto al de carnaval por la última dictadura en 1978, aunque este último fue repuesto en 2011.

${ }^{14}$ Tania Osses es fundadora de la agrupación de danza andina Tinkus Legua y participa de la Casa de la Cultura en la población La Legua, comuna de San Joaquín.

${ }^{15}$ Estructura formada por cañas dulces en forma de trípode en la cual se afirman las hojas superiores al tablón o mesa que sirve de base (Fernández, 1998).

${ }^{16}$ Prenda rectangular de colores fuertes y contrastantes con diversos diseños, preferentemente franjas. Es usada como adorno, mantel, bolso para llevar a un bebé o diversas cosas, o como abrigo. Es de origen altiplánico, usado principalmente por mujeres.

${ }^{17}$ Marcelo Cornejo es músico, fundador de la agrupación Wiñay Katari, ha participado de diversas agrupaciones de danza y música andina en la ciudad de Santiago.

${ }^{18}$ José "Patara" Segovia es un dirigente afro-aymara fundador de la agrupación musical andina Arak Pacha y de la CONACIN, además de ser guardián del Apu Wechuraba, nombre ceremonial con que se conoce a Cerro Blanco, ubicado en la comuna de Recoleta.

\section{Referencias}

Aláez García, Argimiro (2001). "Duelo andino: sabiduría y elaboración de la muerte en los rituales mortuorios". En Chungará, 33(2), 173-178.

Aquino, Salvador (2003). "Cultura, identidad y poder en las representaciones del pasado: El caso de los zapotecos serranos del norte de Oaxaca, México". En Estudios Atacameños, 26, 71-80.

Bastien, Joseph William (1996). La montaña del cóndor: metáfora y ritual en un ayllu andino. La Paz: Hisbol.

Bengoa, José (2007). “Chile mestizo”. En Mensaje, 56(564), 48-50.

Berg, Hans van Den (1989). "La celebración de los difuntos entre los campesinos aimaras del Altiplano". En Anthropos, 84, 115-175.

Brow, James (1990). Notas sobre comunidad, hegemonía y los usos del pasado. Austin: Universidad de Texas.

Bustamante, Patricio (2006). "Santiago de Nuevo Extremo iuna ciudad sin pasado?”. En Revista Centro de Estudios Arquitectónicos Urbanísticos del Paisaje, 9, 1-10.

Canelo, Brenda (2006). Migrantes del área andina centraly Estado porteño ante usos y representaciones étnicamente marcados de espacios públicos. Buenos Aires: CLACSO, ASDI.

Canelo, Brenda (2013). "Día de los difuntos iQué tenés ahí?”. En Revista Anfibia, diciembre, 1-4. Disponible en http://revistaanfibia.com/ensayo/que-tenes-ahí/

Carsten, Janet (ed.) (2000). Cultures of Relatedness. New Approaches to the Study of Kinship. Cambridge: Cambridge University Press.

Castells, Manuel (2003). La era de la información. El poder de la identidad. México: Siglo XXI.

Fernández, Francisca (2018). "Memorias en resistencia: festividades y ritualidades andinas en Santiago de Chile". En Revista Athenea Digital, 18(1), 269-291.

Fernández, Francisca y Francisca Michel (2014a). Conmemorando a nuestros muertos. Festividades y ritualidades en el Día de Difuntos. Santiago de Chile: Ocho libros.

Fernández, Francisca y Francisca Michel (2014b). "Resignificación de la muerte en Los Andes: La festividad del Wiñay Pacha o Todas Almas en Santiago de Chile". En Antropología del Sur, 1(2), 55-65. 
Fernández, Gerardo (1998). "Todos Santos: Todas Almas”. En Revista Andina, 16(1).

Fernández, Gerardo (2006). "Apxatas de difuntos en el altiplano aymara de Bolivia”. En Revista Española de Antropología Americana, 36(1), 165-182.

Ferraro, Emilia (2004). Reciprocidad, don y deuda. Formas y relaciones de intercambios en los Andes de Ecuador: la comunidad de Pesillo. Quito: Abya Yala.

Giménez, Gilberto (2001). "Cultura, territorio y migraciones. Aproximaciones teóricas”. En Alteridades, (22), 5-14.

Grimson, Alejandro (2012). Mitomanías argentinas. Cómo hablamos de nosotros mismos. Buenos Aires: Siglo XXI.

Hidalgo, Cecilia (comp.) (2011). Etnografías de la muerte, rituales, desapariciones, $\mathrm{VIH} /$ sida y resignificación de la vida. Buenos Aires: Ciccus.

Isla, Alejandro (2003). "Los usos políticos de la memoria y la identidad". En Estudios Atacameños, 26, 35-44.

Kauffman, Federico (2010). Ultratumba entre los antiguos peruanos. Lima: Runa Yachachiy.

Maldonado, Benjamín (2002). Autonomía y comunalidad india: enfoques y propuestas desde Oaxaca. Oaxaca: CONACULTA, INAH.

Mardones, Pablo (2016). Buenos Aires Jacha Marka. Migrantes aymaras y quechuas en Buenos Aires. En los umbrales de un nuevo pachakutik. Tesis de Doctorado, Universidad de Buenos Aires.

Mardones, Pablo (2019). "Migramos y nos dimos cuenta de que éramos indios. La migración aymara-quechua en Buenos Aires". En Jessica Nájera, David Lindstrom y Silvia Giorguli (eds.), Migraciones en las Américas. México: COLEF, BIARI, pp. 263-288.

Mardones, Pablo (2020). "Migrar, morir y seguir perteneciendo. El día de los Muertos centroandino del cementerio de Flores de Buenos Aires". En Estudios Atacameños, 64, 361-390.

Mardones, Pablo y Francisca Fernández (2017). "Cinco siglos resistiendo: la marcha del 12 de octubre en
Buenos Aires y Santiago de Chile como memoria colectiva cronotrópica y de reivindicación amerindia en Abya Yala." En Si Somos Americanos, 16(2), 143-171.

Massone, Claudio (1978). Cerro Blanco, antropología de un asentamiento humano. Tesis de licenciatura en Antropología, mención Arqueología, Universidad de Chile, Santiago.

Milla Villena, Carlos (1983). Génesis de la cultura andina. Lima: Fondo Editorial C.A.P.

Mora, Ana Sabrina (2013). "Corporalidades reflexivas, resistencias encarnadas". En Question, 1(38), 28-41.

Ochoa, Víctor (1974). "Todos los Santos en la cultura aymara". En Boletín Instituto de Estudios Andinos, 12, 1-4.

Rappaport, Joanne (2007). "Más allá de la escritura: la epistemología de la etnografía en colaboración”. En Revista Colombiana de Antropología, 43, 197-229.

Rengifo, Grimaldo (1996), El ayllu [documento inédito]. Lima. Disponible en http://www.geocities.ws/isquitipe/ayllu.pdf

Rivera Cusicanqui, Silvia (2010). Principio Potosí reverso. Otra mirada a la totalidad. Madrid: Museo Nacional Centro de Arte Reina Sofía.

Rossells, Beatriz (2009). "100 años de carnaval de la Paz, las identidades del siglo XX”. En Beatriz Rossells et al., Carnaval Paceño y Jisk'a Anata. La Paz: Instituto de Estudios Bolivianos, pp. 13-22.

Scott, James C. (2000). Los dominados y el arte de la resistencia. México: Era.

Stehberg, Rubén y Gonzalo Sotomayor (2012). "Mapocho incaico". En Boletín del Museo Nacional de Historia Natural, 61, 85-149.

Taypi Aru (2011). Santiago Jacha Marka: danzas, cosmovisión, festividades y acción política en el espacio urbano. Santiago: Quimantú.

Tedlock, Barbara (1991). "From Participant Observation to the Observation of Participation: The Emergence of Narrative Ethnography". En Journal of Anthropological Research, 47(1), 69-94. 
Foto 1. Ch'allando nuestro difunto

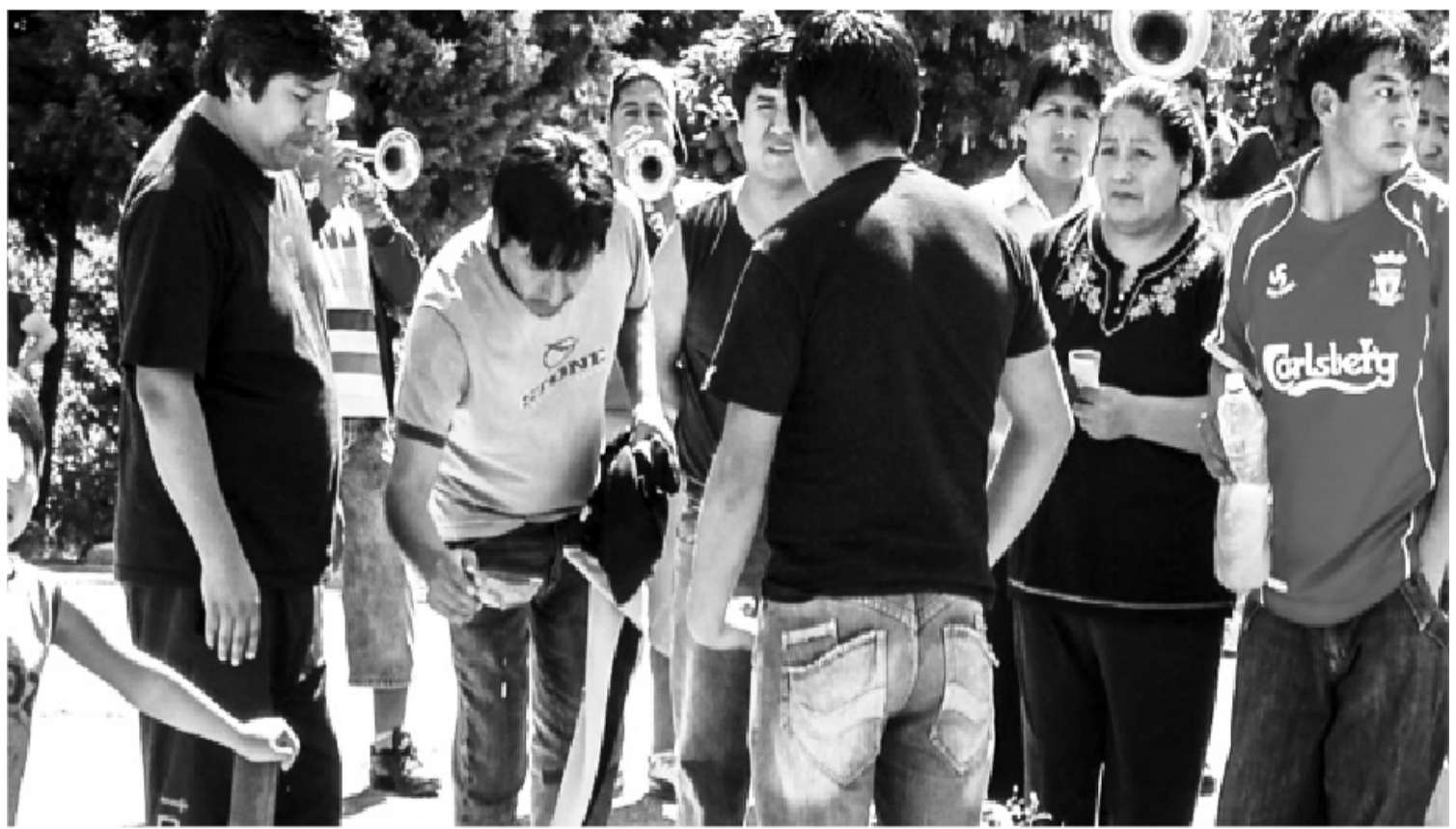

Fuente: registro propio, Buenos Aires, Argentina, 1 de noviembre de 2010.

Foto 2. T'antawawas

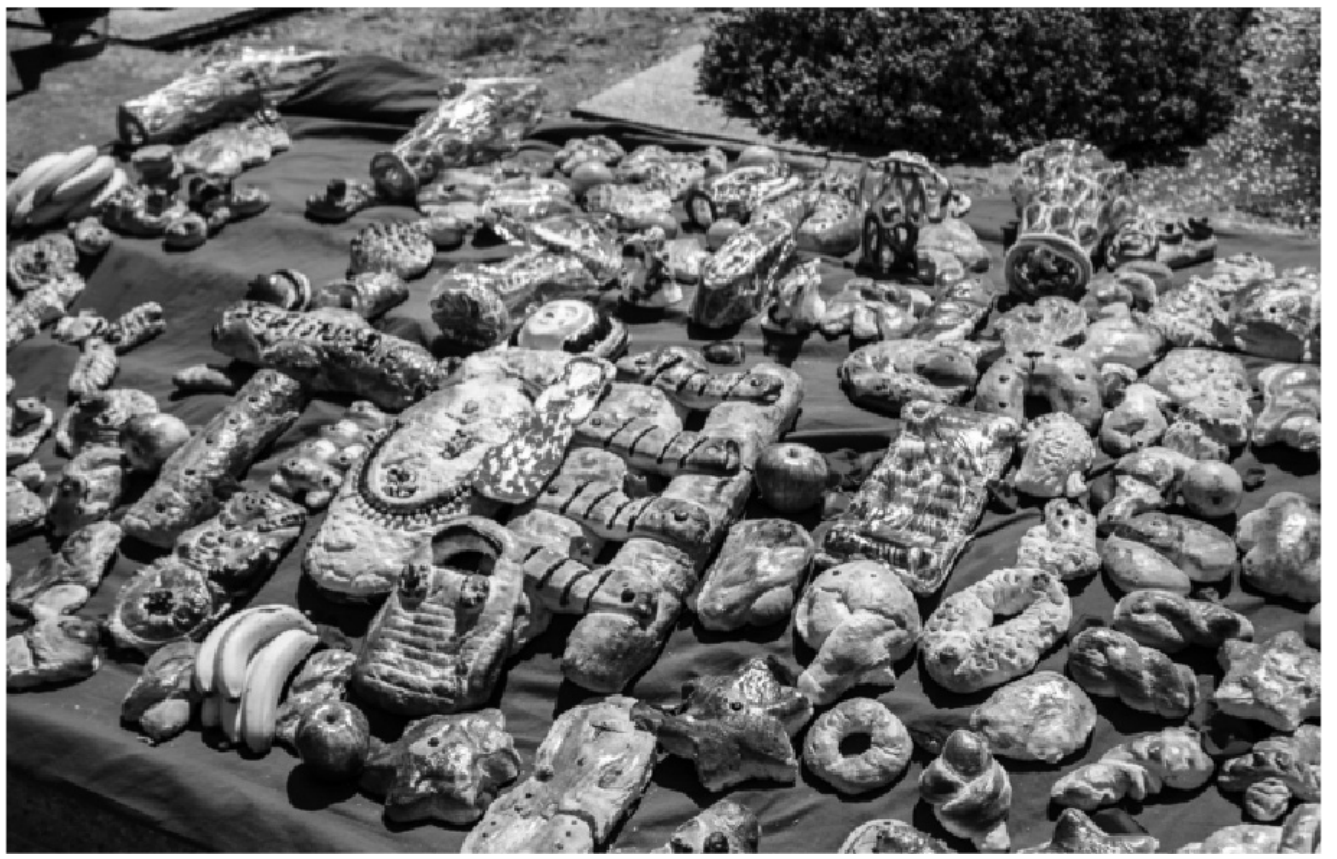

Fuente: registro propio, Buenos Aires, Argentina, 2 de noviembre de 2013. 
Foto 3. Mesa fúnebre de Manuel Remonte

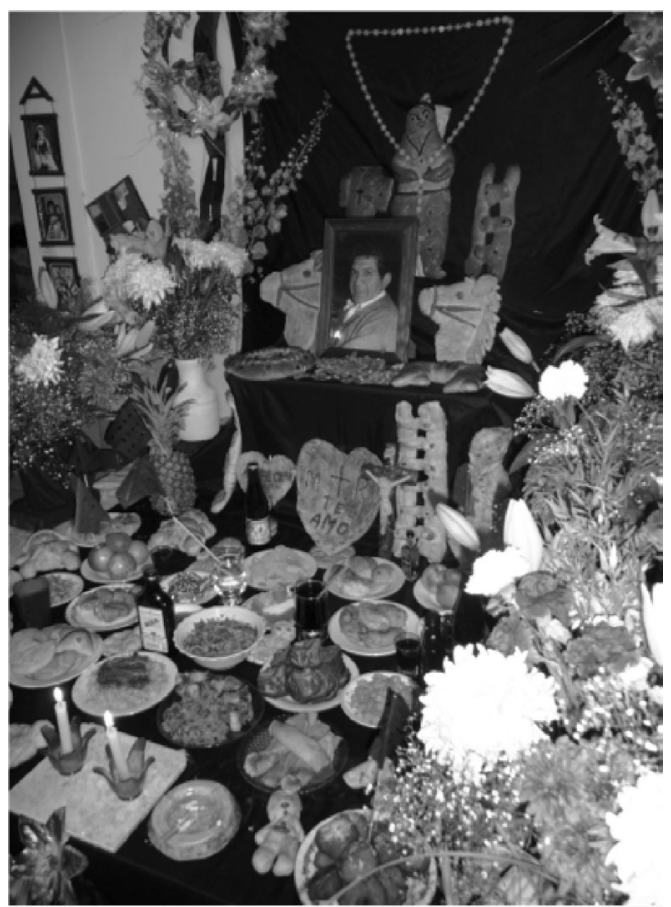

Fuente: registro propio, Buenos Aires, Argentina, l de noviembre de 2011.

Foto 4. Lakitas del Oriente

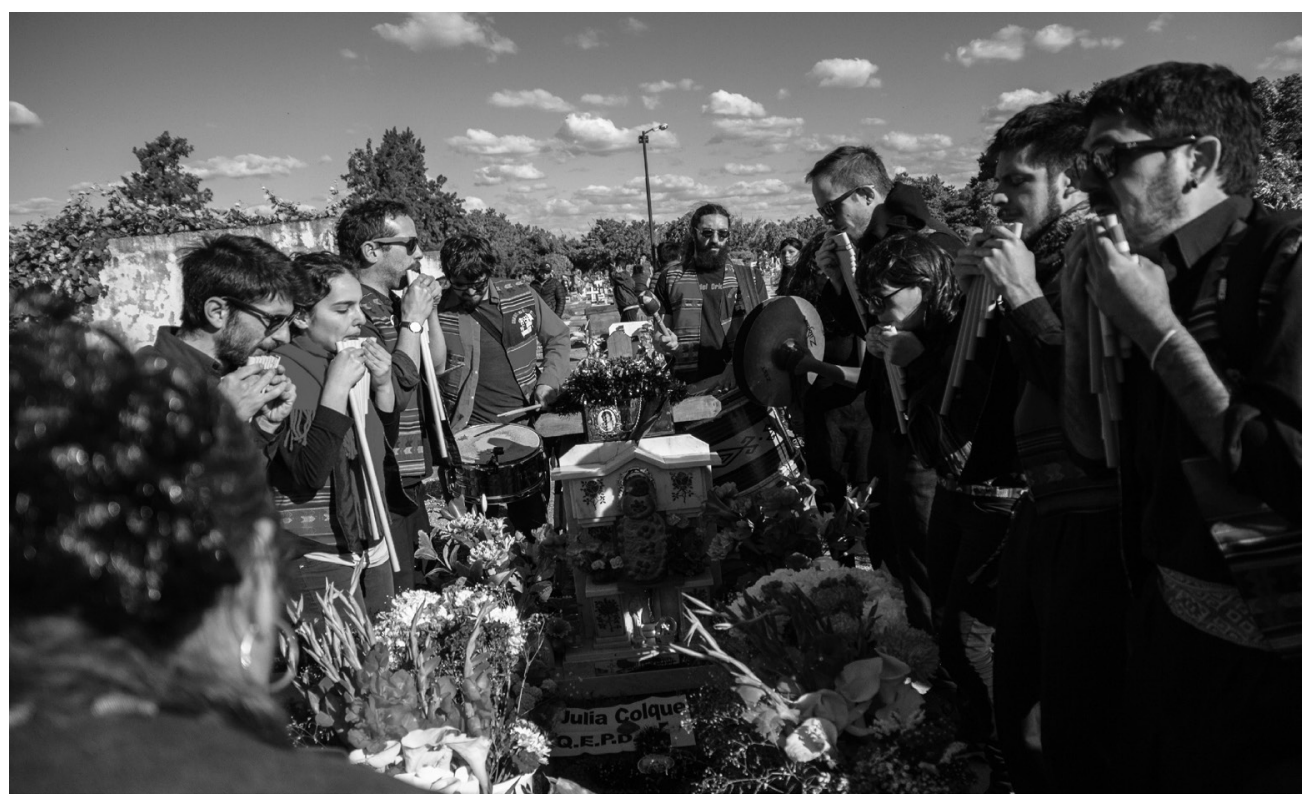

Fuente: foto de Tamara Fernández, Buenos Aires, Argentina, 2 de noviembre de 2016. 
Foto 5. Tarkeada comunitaria en Cerro Chena

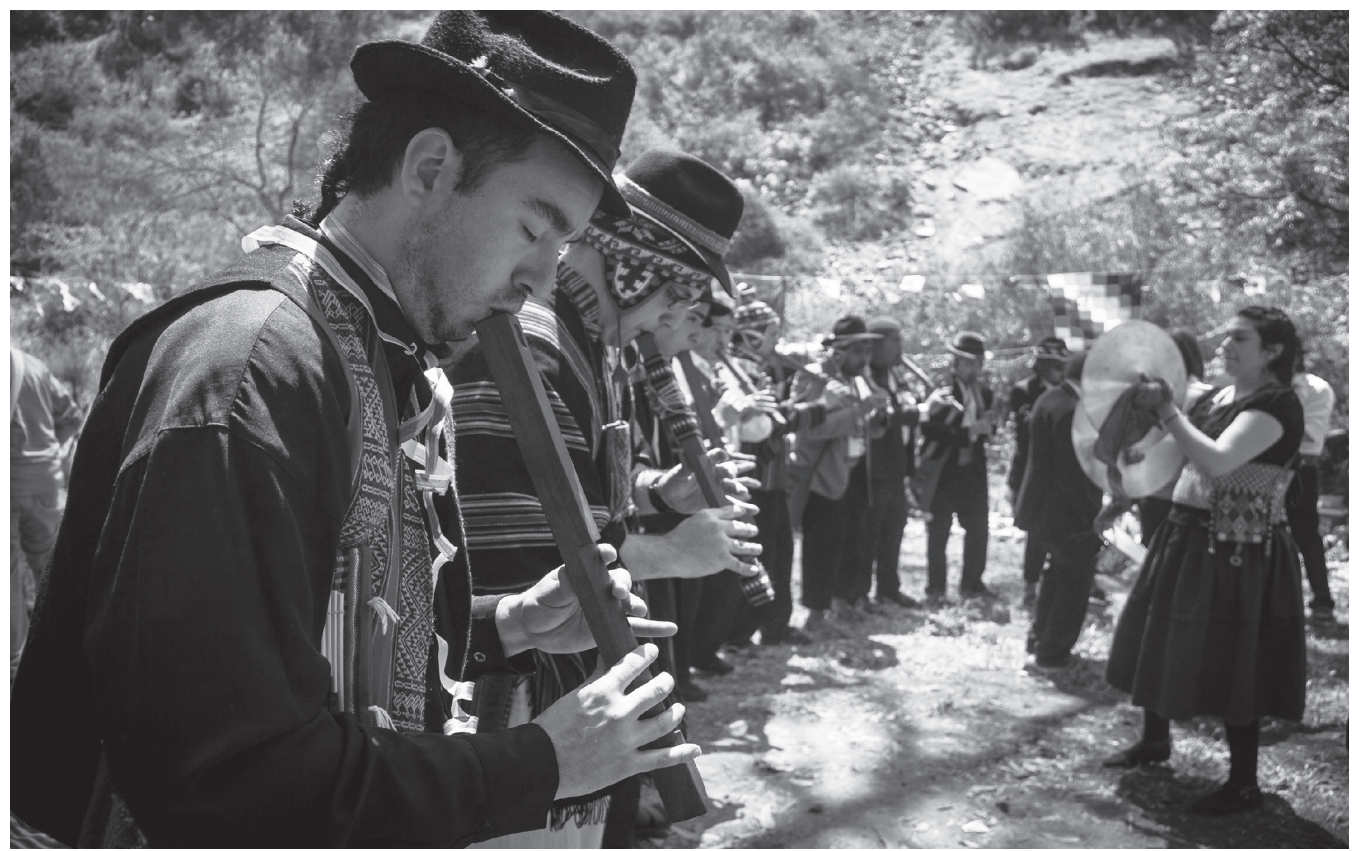

Fuente: foto de Miguel Hidalgo Espinoza, Santiago, Chile, 1 de noviembre de 2013.

Foto 6. Tarkeada por Wiñay Katari en el Patio 29 del Cementerio General

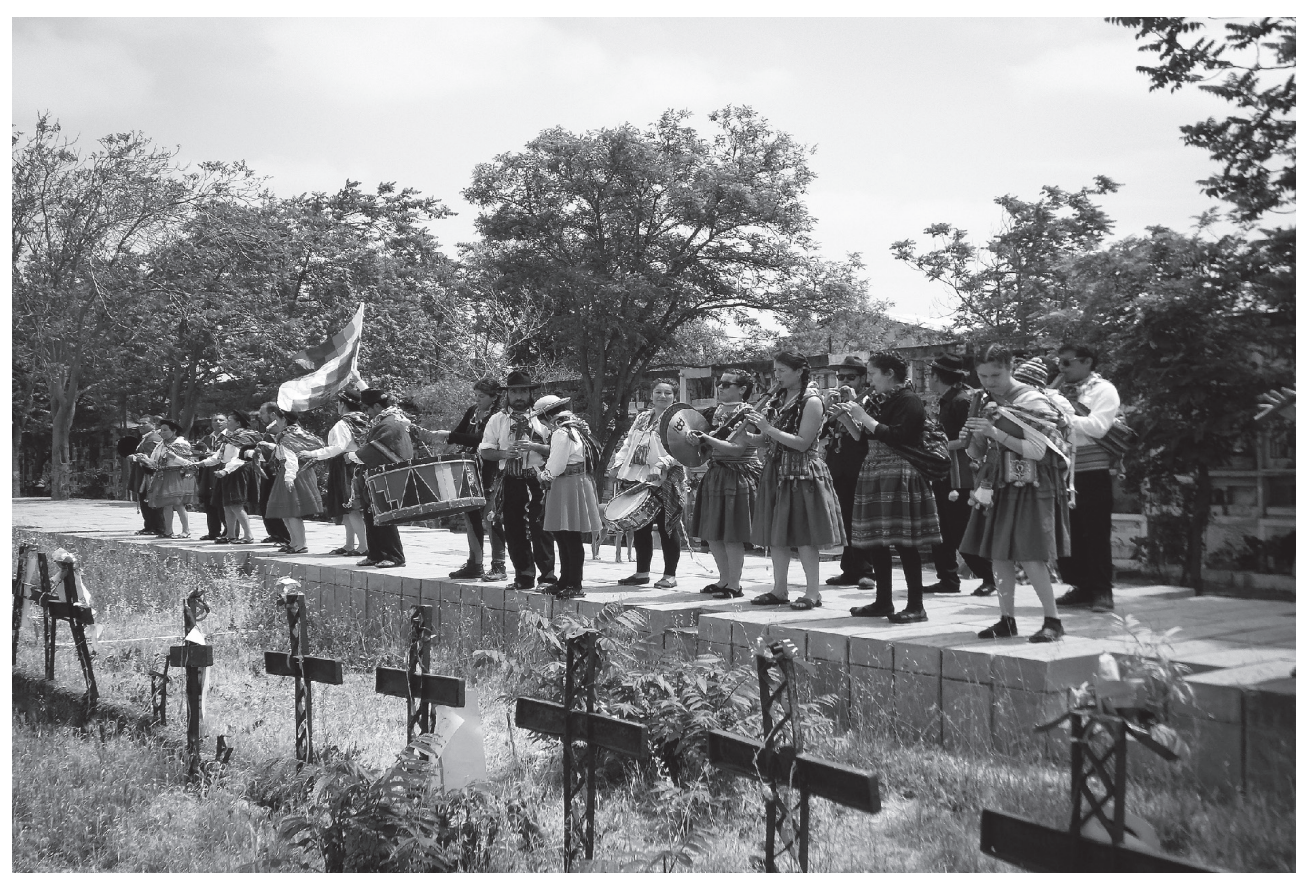

Fuente: foto de Miguel Hidalgo Espinoza, Santiago, Chile, 1 de noviembre de 2013. 
Foto 7. Mesa ceremonial en Casa Andina de Cerro Blanco

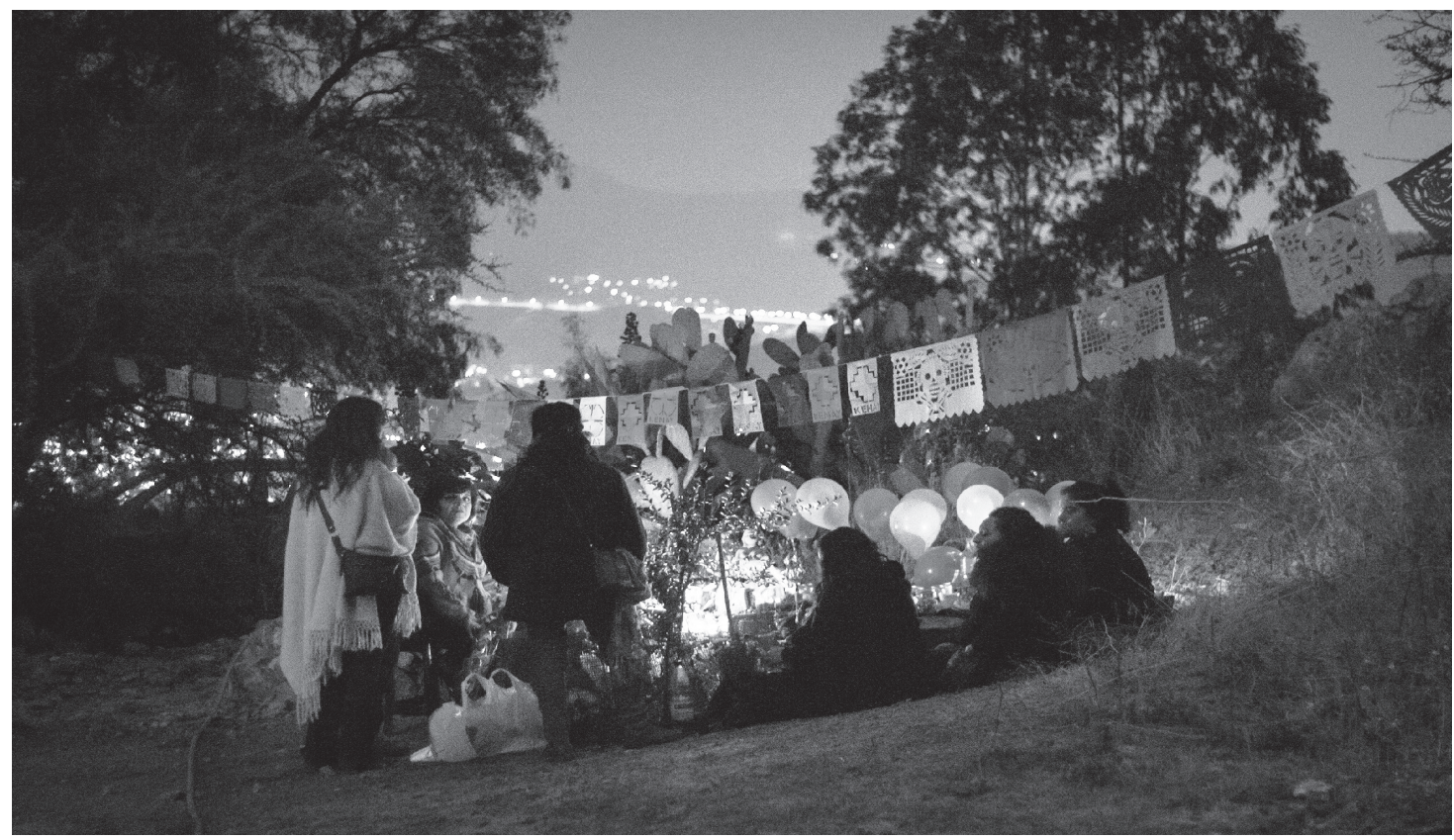

Fuente: foto de Miguel Hidalgo Espinoza, Santiago, Chile, 31 de octubre de 2013.

Foto 8. Mesa de difuntos en Cerro Chena

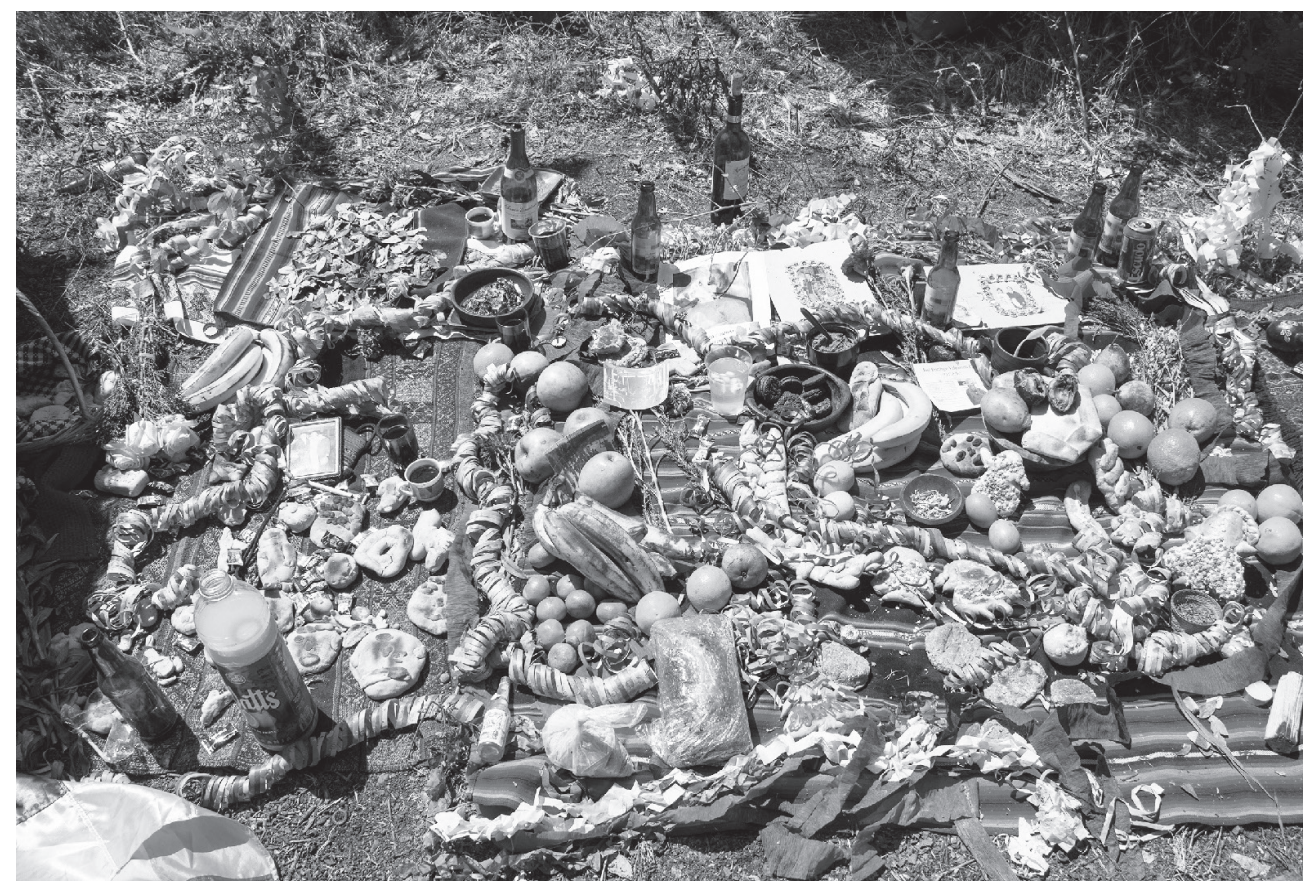

Fuente: foto de Miguel Hidalgo Espinoza, Santiago, Chile, 1 de noviembre de 2013. 